\title{
Research on "The Belt and Road" Cross-border Logistics Talent Cultivation from the Perspective of Higher Vocational Education Supply-side Reform
}

\author{
Li Xudong, Zeng Yanying \\ School of Transportation and Economic Management, Guangdong Communication Polytechnic \\ Guang Zhou, China \\ E-mail address: li_xudong@163.com
}

\begin{abstract}
This paper focuses on the "quality" of the talent supply-side in the higher vocational education rather than the "quantity" of the talent demand-side. With "the optimization of the talent supply structure and the improvement of the talent supply quality" as the core, based on the higher requirement from the implementation of "the Belt and Road" strategy for the cultivation quality of cross-border logistics talent in the higher vocational education, this paper explores the teaching reform in higher vocational education from the perspective of the supplyside; this paper also specifically proposes the basic path of the supply-side reform for cross-border logistics talent in the higher vocational education under "the Belt and Road" strategy and points out main difficulties and their countermeasures of that reform from such aspects as the optimization of talent supply structure, the adjustment of the professional curriculum system, the enhancement of deficiencies in students' practical ability, and the improvement of the quality assessment of talent cultivation.
\end{abstract}

Keywords-higher vocational education; supply-side reform; "the Belt and Road" strategy; cross-border logistics talent; talent cultivation quality

\section{INTRODUCTION}

Unimpeded trade is an important goal for implementing China's "the Belt and Road" strategy, and to realize this goal, cross-border logistics is the key support. Significant differences between "the Belt and Road" trade and the traditional one on the cross-border logistics mode are the facilitation of the customs clearance, the cross-border freight integration and so on [1]; this new cross-border logistics mode raises higher demands to the professional ability of practitioners so that many higher vocational colleges face further challenges in the promotion of the cross-border logistics talent cultivation quality. For a long time, the higher vocational education pays more attention to the "quantity" of the talent demand-side, while the supply-side reform provides new ideas for cracking problems faced by improving the quality of cross border logistics talent cultivation [2]. This paper converts the previous perspective on the "quantity" of the talent demand-side to the point of view that pursues the "quality" of talent supply-side, explores the supply-side reform of higher vocational education, and puts efforts to improve the quality and efficiency of "the

FOUNDATION PROJECT :2017 Traffic and Transport Vocational Education Scientific Research Key Project (Project Number: 2017A02) "Research on 'The Belt and Road' Customs Declaration \& International Freight Talent Cultivation from the Perspective of Supply-side Reform", Approved by China's National Traffic and Transport Vocational Education \& Teaching Steering Committee.
Belt and Road" cross-border logistics talent supply.

II. Motivation ANALYSIS OF THE SUPPLY-SIDE REFORM IN CROSS-BORDER LOGISTICS TALENT OF THE HIGHER VOCATIONAL EDUCATION UNDER "THE BELT AND ROAD" STRATEGY

\section{A. Higher Requirements from "the Belt and Road" Unimpeded Trade Pattern for Cross-border Logistics Talent Cultivation Quality}

At present, the implementation of "the Belt and Road" strategy enters into a new important stage, and talent is the supporting point and the crux of "the Belt and Road" development [3]. To adapt to the growing trend of "the Belt and Road" unimpeded trade, the majority of cross-border logistics enterprises speed up the upgrading of cross-border logistics services and adjust the core areas of business; in-depth regulation has been made in enterprise-related jobs, and typical tasks have set higher requirement for the professional core competence of employees; the key points of talent demand-side changes and the organic link between them optimize the talentsupply structure for supply-side logistics majors of the higher vocational education, adjust the talent training objectives, improve the research of talent supply quality, and provide the reform with direct motivation and internal drive.

\section{B. The Necessity of Improving "the Belt and Road" Cross-border Logistics Talent Cultivation from the Higher Vocational Education Supply-side}

At this stage, the supply structure of cross-border logistics talent in higher vocational colleges needs to be optimized urgently. In the context of accelerating "the Belt and Road" development, the middle and low-end talent oriented to traditional trade are redundant, but cross-border logistics talen adapted to the "the Belt and Road" strategy is in short supply; meanwhile, cross-border logistics talent quality needs to be improved, the professional curriculum system updates slowly, and the relevant course content in the field of traditional crossborder logistics business is outdated, badly matching the unimpeded trade business mode of "the Belt and Road". Therefore, it's necessary to build the professional curriculum 
system centered on facilitation of the customs clearance and transport skills training of cross-border integration. In addition, as a result of lack of innovation in the practical teaching mode of higher vocational colleges and heavy reliance on schoolenterprise cooperation over the years, employers have gradually lost impetus for cooperation and enthusiasm for participating in practical teaching, and the phenomenon of "fake cooperation between schools and enterprises" has become increasingly serious. In this case, based on supply-side, thoughts should be innovative and, and the supply-side reform of the higher vocational education should be deepened [4]; with supply-side as the leading, deep integration of schools and enterprises as well as production and teaching docking should be effectively promoted; renovate and activate schoolenterprise cooperation mechanism, innovate and reform practical teaching mode, and great efforts should be made to improve the practical ability of graduates. All of these is to adapt to actual demand for cross-border logistics talent in the new phase of "the Belt and Road".

\section{THE BASIC PATH OF CROSS-BORDER LOGISTICS TALENT SUPPLY-SIDE REFORM IN THE HIGHER VOCATIONAL \\ EDUCATION UNDER "THE BELT AND ROAD" STRATEGY}

Under the guidance of supply-side reform theory, focusing on " the adjustment of supply-side structure and the improvement of the supply-side shortage ", taking the logistics management major of the higher vocational education as an example, the cross-border logistics talent supply-side reform should be significantly enhanced in four aspects including the optimization of the talent supply structure, the adjustment of the professional curriculum structure, the promotion of practical ability, and the improvement of the evaluation mechanism. The basic path of cross-border logistics talent supply-side reform under "the Belt and Road" strategy is shown in Figure 1.

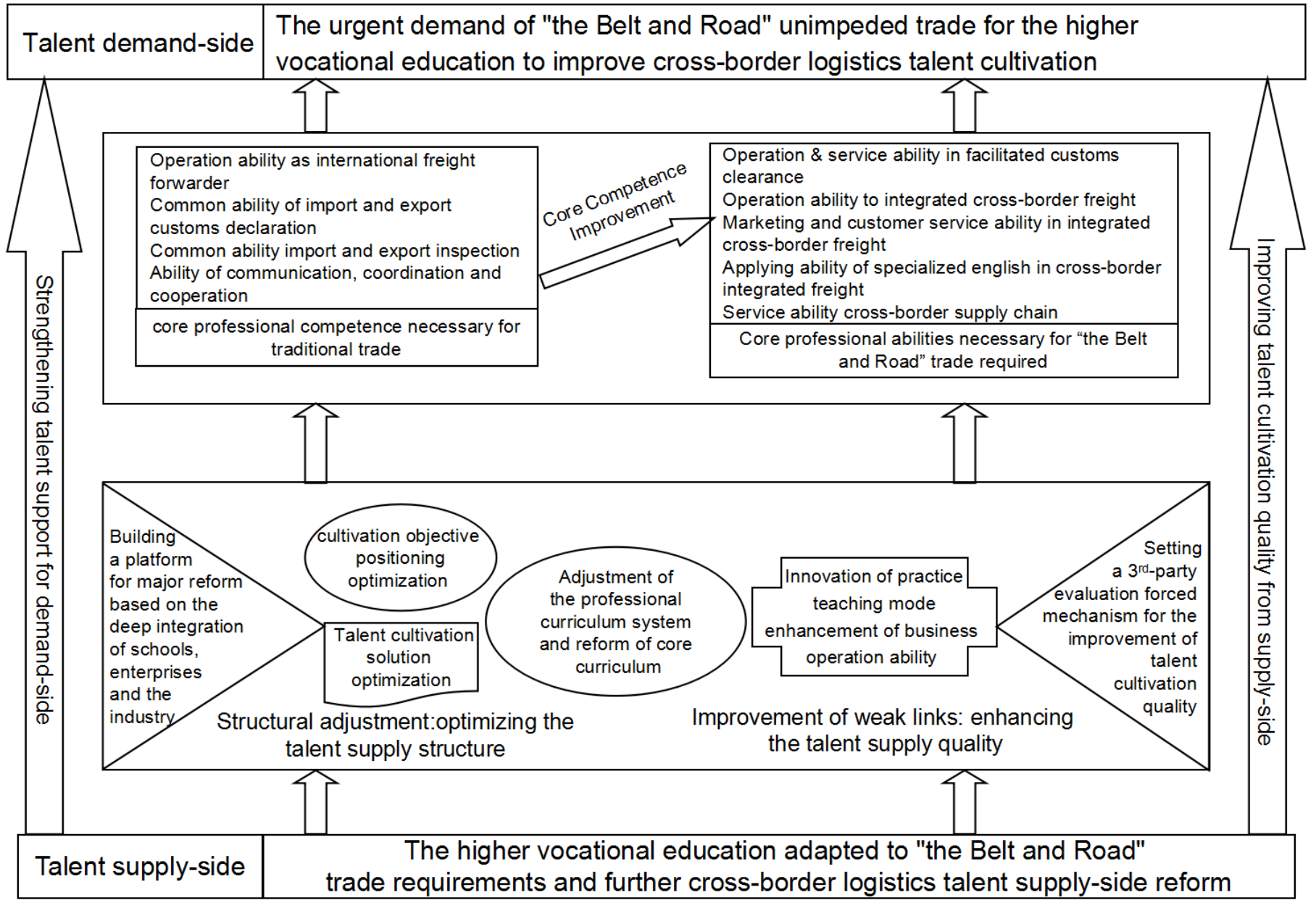

Fig. 1 The basic path of cross-border logistics talent supply-side reform in the higher vocational education under "the Belt and Road" strategy 


\section{A. Optimization of the Talent Supply Structure and Emphasis on Cultivating three kinds of Cross-border Logistics Highly Skilled Talent}

Adjust the orientation of talent cultivation, optimize the supply structure of cross-border talent. The overall orientation of professional talent cultivation is generally the education of cross-border logistics highly skilled talent adapted to "the Belt and Road" unimpeded trade demand. The talent supply structure can be divided into three categories: first, highly skilled personnel facilitating cross-border customs clearance to adapt to "the Belt and Road" trade needs (properly take into account the traditional foreign trade needs); second, highly skilled personnel integrating cross-border freight, whose abilities of operation, marketing and customer service in the integration of cross-border freight and vocational English application should be seriously trained; Third, high-skilled personnel providing cross-border supply chain services, who will be cultivated the abilities of cross-border supply chain management and cross-border warehousing and distribution; In terms of professional key quality, great efforts should be made to help the three types of talent cultivate the humanistic knowledge and literacy of countries along "the Belt and Road", as well as cross-border team spirit and logistics legal sense. Based on mentioned above, optimize the talent training program of logistics management and adjust the professional curriculum system. The cross-border logistics talent supply structure of the higher vocational education adapted to "the Belt and Road" unimpeded trade requirements is shown in Table 1.

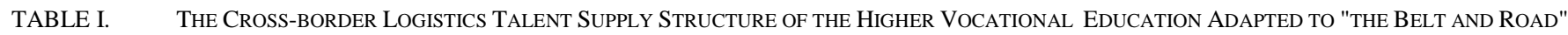
UNIMPEDED TRADE REQUIREMENTS

\begin{tabular}{|c|c|c|c|}
\hline $\begin{array}{l}\text { Overall orientation } \\
\text { of talent cultivation }\end{array}$ & \multicolumn{3}{|c|}{$\begin{array}{c}\text { Cultivation of cross-border logistics highly skilled talent adapted to "the Belt and Road" } \\
\text { unimpeded trade requirements }\end{array}$} \\
\hline \multirow{2}{*}{$\begin{array}{l}\text { Core business } \\
\text { oriented }\end{array}$} & \multicolumn{3}{|c|}{ Cross-border integrated logistics supporting "the Belt and Road" unimpeded trade } \\
\hline & $\begin{array}{l}\text { "The Belt and Road" cross- } \\
\text { border customs clearance } \\
\text { facilitation }\end{array}$ & $\begin{array}{l}\text { "The Belt and Road" cross-border } \\
\text { integration of freight }\end{array}$ & $\begin{array}{c}\text { "The Belt and Road" } \\
\text { cross-border supply chain } \\
\text { services }\end{array}$ \\
\hline $\begin{array}{l}\text { Three main types } \\
\text { of cultivating cross- } \\
\text { border logistics } \\
\text { talent }\end{array}$ & $\begin{array}{l}\text { Highly skilled talent } \\
\text { facilitating cross-border } \\
\text { customs clearance }\end{array}$ & $\begin{array}{l}\text { Highly skilled talent integrating } \\
\text { cross-border freight }\end{array}$ & $\begin{array}{l}\text { High-skilled talent } \\
\text { providing cross-border } \\
\text { supply chain services }\end{array}$ \\
\hline $\begin{array}{l}\text { Three groups of } \\
\text { core abilities } \\
\text { for training cross- } \\
\text { border logistics } \\
\text { talent }\end{array}$ & $\begin{array}{l}\text { A. Operational capacity of } \\
\text { cross-border customs } \\
\text { clearance facilitation } \\
\text { B. Service capability of } \\
\text { cross-border customs } \\
\text { clearance facilitation }\end{array}$ & \begin{tabular}{|} 
A. Operational capacity of integration \\
of cross-border freight \\
B. Marketing capacity of integration \\
of cross-border freight \\
C. Customer service capacity of \\
integration of cross-border freight \\
D. Cross-border freight professional \\
English application capacity \\
\end{tabular} & $\begin{array}{c}\text { A. Management capability } \\
\text { of cross-border supply } \\
\text { chain } \\
\text { B. Cross-border } \\
\text { warehousing and } \\
\text { distribution capability }\end{array}$ \\
\hline $\begin{array}{l}\text { Three core qualities } \\
\text { for cultivating } \\
\text { cross-border } \\
\text { logistics talent }\end{array}$ & \multicolumn{3}{|c|}{$\begin{array}{l}\text { Humanistic knowledge and literacy of countries along "the Belt and Road", as well as cross- } \\
\text { border team-work spirit and logistics legal sense }\end{array}$} \\
\hline
\end{tabular}

B. Adjustment of the professional curriculum system and enhancement of "the Belt and Road" cross-border logistics integrated skills

Supplement and improve "the Belt and Road" cross-border logistics business-related courses, and build the logistics management professional curriculum system focus on cultivating the key skills including cross-border customs clearance facilitation, integration of cross-border freight and cross-border supply chain services. The establishment of a scientific and rational professional curriculum system is the core link to ensure "the Belt and Road" cross-border logistics personnel training quality. It is necessary to accommodate to new requirements from "the Belt and Road" cross-border logistics business for new posts, optimize and adjust the curriculum structure, and effectively improve the structure to match facilitation of customs clearance, integration of crossborder transport, cross-border supply chain services and other key areas of business. It is imperative to ensure the coupling of courses and posts, and the enhancement of the match level between the professional core curriculum ability objectives and competency standards of main jobs like operation, marketing, customer service. Taking ability training as the core, a new professional curriculum system should be built by following trails: identify core business areas $\rightarrow$ analyze major posts $\rightarrow$ analyze typical work tasks $\rightarrow$ cultivate professional core competencies $\rightarrow$ improve courses and modules settings $\rightarrow$ promote teaching and learning with skills competition. The curriculum system of cross-border logistics talent cultivation in higher vocational education under "the Belt and Road" strategy is shown in Figure 2. 


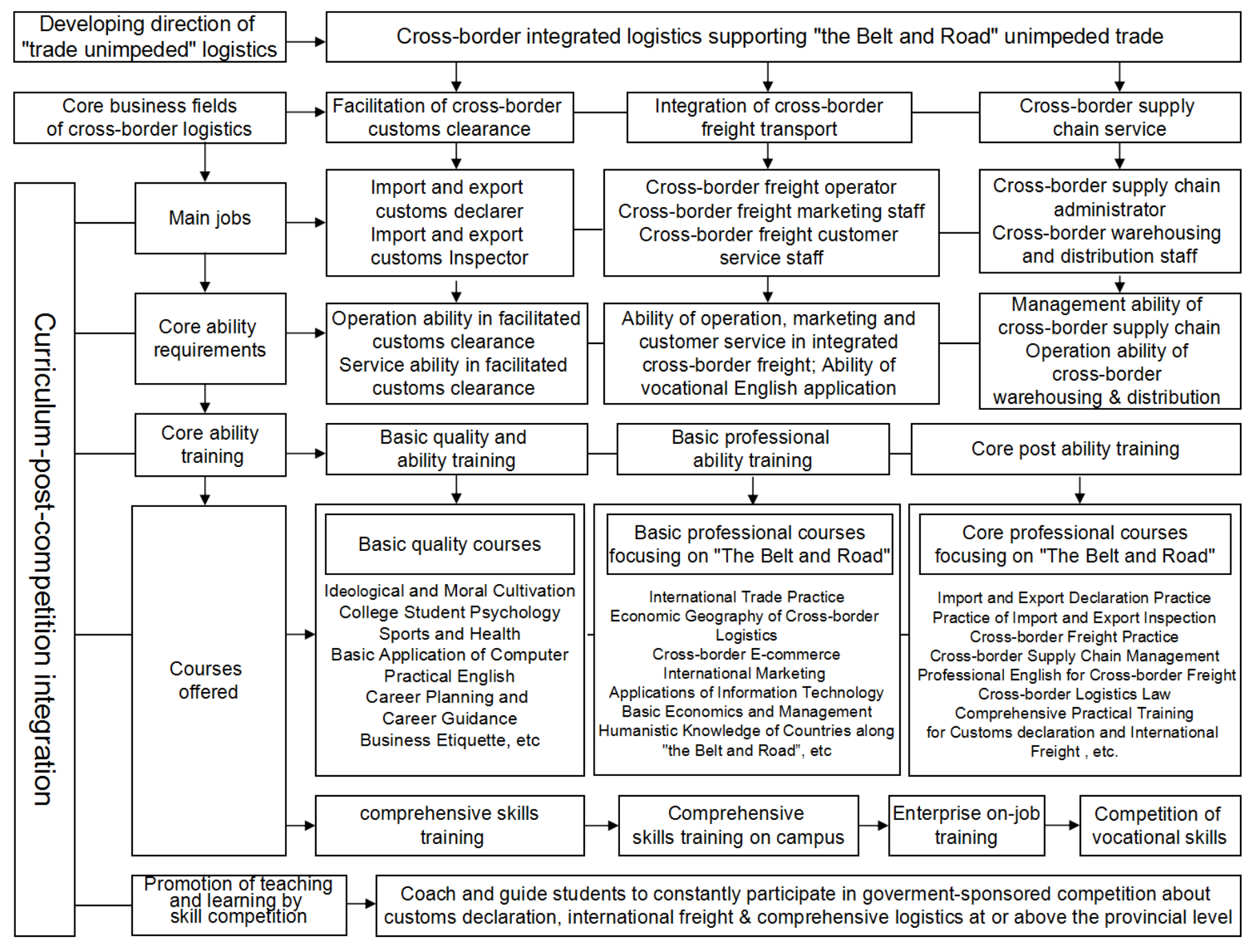

Fig. 2 The curriculum system adjustment of cross-border logistics talent cultivation in higher vocational education under "the Belt and Road" strategy

On the basis of curriculum system adjustment, deepen the reform of professional core curriculum. It is essential to accommodate to requirements of "the Belt and Road" crossborder logistics business posts, and effectively promote the professional core curriculum reform including "import and export declarations practice", "cross-border freight practice", and "cross-border supply chain management". Utilize systematic thinking of developing vocational education curriculum system, following "new jobs $\rightarrow$ new work tasks $\rightarrow$ new ability requirements $\rightarrow$ new learning situation $\rightarrow$ new learning unit" development path [5], to ensure a good match between the teaching content of the new curriculum and cross-border logistics new business under "the Belt and Road", between curriculum competency objectives and business capacity requirements, and to make sure that students master "the Belt and Road" cross-border logistics business comprehensive skills.

\section{Improvement of practical ability and seamlessly dock "the Belt and Road "cross-border logistics work requirements}

Innovate "Internet plus the post practice platform" practical teaching mode, enhance students' ability to do business, establish post practice bases in all cooperative enterprises, explore the dual tutorial system of both enterprise practice teachers and school full-time teachers guiding students to practice, effectively improve guidance and comprehensive assessment of students' internship process, and practically promote the quality of practice teaching; focus on promoting the development of dual-teacher oriented teaching team. On the one hand, the practical teaching level of full-time teachers should be improved by way of post practice; on the other hand, the technical and business backbone of cross-border logistics enterprises in "the Belt and Road" region should be employed to bear a certain proportion of practice teaching and guidance. That team can practically remedy students' business practice ability problems, and seamlessly dock "the Belt and Road "cross-border logistics work requirements. 


\section{Improvement of evaluation mechanism weak links and the initiative to force the talent cultivation quality to enhance}

Strive to improve the quality evaluation of talent cultivation and build the third party independent evaluation forced mechanism for cultivation quality enhancement. For a long time, the evaluation of the quality of personnel training is based on students, teachers, teaching and educational departments, so evaluation results are not objective. In order to improve the reliability and depth of the talent cultivation quality, as well as enhance strength and effect of forced the promotion of teaching quality by the quality evaluation, in-depth cooperation with the authority of domestic third-party education evaluation agencies should be developed, and taking previous graduates and typical employment unit as the survey subject, an extensive investigation on the quality of professional personnel training should be conducted. According to problems from the investigation report, effective action should be taken to improve the match between talent quality and requirements of "the Belt and Road" cross-border logistics talent, and to effectually enhance the professional talent support for crossborder logistics industry enterprises.

\section{DIFFICULTIES IN REFORM AND ITS COUNTERMEASURES}

\section{A. A deep analysis of specific requirements from "the Belt and Road" unimpeded trade mode for cross- border logistics talent}

Go deep into many typical cross-border logistics enterprises oriented towards "the Belt and Road" region and closely related industry organizations. Through comprehensive investigation and interviews, deeply analyze the development trend of "the Belt and Road" unimpeded trade mode, cross border logistics business transformation and upgrading, related job setting adjustment, as well as typical job updates and their higher requirements for professional core competencies. How to ensure the reliability and depth of the research results and conclusions to the greatest extent is a major difficulty and one of the key points in the reform. Only by effectively solving this difficulty can scientific and objective basis be provided for the subsequent research and practice of optimizing the supply structure of cross-border logistics talent and improving the talent supply quality.

\section{B. The orientation of talent supply-side and the continuous improvement of school-enterprise deep integration and production and teaching seamless docking}

Higher vocational colleges should focus on changing the inertial thinking of over-reliance on industry traction for a long time and effectively reverse the passive situation of overreliance on demand-side enterprises to receive graduates, which should be led by talent supply-side (school) and integrated with representative enterprises and cross-border logistics industry organizations of huge effect, taking the initiative to explore the development of the long-term mechanism in which schools and enterprises actively participate in the professional teaching reform, building a platform for improving personnel training based on the deep school-enterprise integration, focusing on optimizing the "the Belt and Road" cross-border logistics talent supply structure, improving the talent supply quality; only by deep integration as well as the continuous improvement of production and teaching seamless docking can higher vocational colleges accurately adjust the orientation of talent training, improve the personnel training program, formulate the professional supplyside reform strategy correctly, optimize the specialized curriculum system in time, effectively enhance students' business practice ability, and dramatically improve the major support for enterprise talent [6].

\section{Improvement of quality evaluation weak links as well as the building of the third-party independent evaluation and forced cultivation quality improvement mechanism}

According to the intensive investigation of recent graduates' professional competence and comprehensive competitiveness for the posts of "the Belt and Road" cross-border logistics business, only by focusing on getting rid of the long-standing abuse of the talent training and quality evaluation system in which "athletes becoming referees" , exploring bravely and conducting in-depth cooperation with China's authoritative and independent third-party educational evaluation institutions can the objectivity and facticity of the personnel training quality evaluation data be effectively guaranteed and the talent-supply quality defects be really improved; on the other hand, taking the evaluation result as the important basis and the short board of practical talent training quality as the starting point, targeted improvement should be made to effectively force this major to enhance the talent supply quality.

\section{CONCLUSION}

The above analysis shows that the higher vocational education should change the perspective of reform, convert the thinking of cultivating talent, take supply-side as main leading, and improve cross-border logistics talent supply quality. At present, the implementation of "the Belt and Road" strategy enters into a new important stage in which talent is the key, so the higher vocational colleges must focus on higher requirements from "the Belt and Road" unimpeded trade for cross-border talent cultivation, know better the basic path of talent supply-side reform, as well as overcome the main difficulties in the reform and take relevant measures. What's more, the higher vocational colleges optimize talent supply structure by three kinds of cross-border logistics talent cultivation and improve the talent supply quality by promoting three groups of cross-border logistics professional Competence as the core, so that effectively enhance talent support from the logistics major in the higher vocational colleges education for implementing the "the Belt and Road" strategy and improve the core competitiveness of the higher vocational colleges and the major. This paper puts forward the educational reform idea and concrete reform measures, aiming at providing reference for the talent cultivation majored in logistics management of higher vocational colleges as well as for teaching reform and research of other cross-border logistics relative specialties. 


\section{ACKNOWLEDGMENT}

Li Xudong (1975- ), male, associate professor of School of Transportation and Economic Management, Guangdong Communication Polytechnic. The main research direction is cross-border logistics. Zeng Yanying (1966- ), female, professor of School of Transportation and Economic Management, Guangdong Communication Polytechnic. The main research direction is logistics management.

\section{REFERENCES}

[1] Vision and Actions on Jointly Building Silk Road Economic Belt and 21st-Century Maritime Silk Road [EB/OL] (2015-3-28).http://news. xinhuanet.com/finance/2015-03/28/c_1114793986.htm.

[2] Lv Jingquan, Ma Yan, Yang Yan, Liu Shu.Vocational Education: Supply-side Structural Reform[J].China Vocational and Technical Education, 2016 (09):15-19.

[3] Zhou Guping, Kan Yue. Talent Support and Education Path of "The Belt and Road" Strategy[J]. Education Research, 2015(10):4-9, 22.

[4] Liang Jiafeng. New perspective of Higher Vocational Education under the Background of Supply-side Reform [J].China Higher Education, 2016 (10): 19-23.

[5] Jiang Dayuan. On Working Process Systematization for Vocational Education Curriculum Development [J].Journal of Xuzhou Vocational of Architectural Technology, 2010, 10 (1): 1-6.

[6] Deng Deai, Li Shulin.Research on Logistics Talent Cultivation under "the Belt and Road" Strategy [J]. Logistics Technology, 2016 (11): 185188. 